J. Clin. Chem. Clin. Biochem.

Vol. 20, 1982, pp. 169-173

\title{
Ultrafiltrable Serum Citrate and the Relationship Between Serum and Urinary Citrate Results in Controls and Renal Calcium Stone Formers
}

\author{
By P. O. Schwille*,D. Scholz** and K. Schwille** \\ Mineral Metabolism and Endocrine Research Laboratory, Departments of Surgery* and Urology**, \\ University Hospital, Erlangen, FRG
}

(Received June 19/October 26, 1981)

Summary: The total and ultrafiltrable citrate of serum were measured in healthy controls, and in patients with calcium-containing kidney stones classified into the various calciuria types (normocalciuria, renal, absorptive, resorptive hypercalciuria). The total citrate in two subgroups (normocalciuria, renal hypercalciuria) was significantly higher than in controls. Two independent analyses showed a mean ultrafiltrable fraction of 0.86 (controls and stone formers, with the exception of resorptive hypercalciuria) and 0.95 (resorptive hypercalciuria), i.e. the calculated extent of binding of citrate to serum macromolecules ( $>10000$ Daltons). The differences in the fraction of free citrate between controls and renal stone formers are not significant. The apparent mean association constants are $(1 / \mathrm{mol}) 0.24 \times 10^{2}$ (controls) and $0.29 \times 10^{2}$ (normocalciuria). There is a high correlation between the ultrafiltrable fraction and total citrate in the serum, and also between the ratios urinary/serum creatinine and urinary/ serum total citrate, during a $2 \mathrm{~h}$ endogenous creatinine clearance in the morning (fasting). These findings suggest that

1) there is citrate binding in the serum,

2) the normal portion of free citrate in total serum citrate of normocalciuric stone formers cannot explain the decreased citrate excretion in $24 \mathrm{~h}$ urine of these subjects,

3) under defined conditions of examination (morning; fasting) urinary citrate is determined largely by the filtered load of citrate in the proximal renal tubule.

\section{Ultrafiltrierbares Citrat im Serum und Beziehungen zwischen Serum- und Urincitrat:}

Ergebnisse bei Gesunden und Untergruppen der Calcium-Urolithiasis

Zusammenfassung: Im Serum wurden Gesamt- und ultrafiltrierbares Citrat bei gesunden Kontrollpersonen sowie Patienten mit calciumhaltigen Nierensteinen, unterteilt in die verschiedenen Calciurie-Typen (Normocalciurie, renale, absorptive, resorptive Hypercalciurie), gemesșen. Das Gesamt-Citrat in zwei Untergruppen (Normocalciurie, renale Hypercalciurie) ist signifikant höher als bei Gesunden. Unter Verwendung zweier unabhängiger Analysen fand sich eine mittlere ultrafiltrierbare Fraktion zwischen 0.86 (Kontrollen; Steinbildner, ausgenommen resorptive Hypercalciurie) und 0,95 (resorptive Hypercalciurie), d.h. eine errechnete Citratbindung an Serum-Makromoleküle $>10000$ Daltons). Die Unterschiede im Anteil des freien Citrats zwischen Kontrollen und Harnsteinkranken sind nicht signifikant. Die scheinbaren mittleren Assoziationskonstanten sind $(1 / \mathrm{mol}) 0,24 \times 10^{2}$ (Kontrollen) und $0,29 \times 10^{2}$ (Normocalciurie). Es besteht eine hohe Korrelation zwischen der ultrafiltrierbaren Fraktion und dem Gesamt-Citrat im Serum, sowie eine ausreịchend hohe zwischen den Quotienten Urin/Serum-Kreatinin und Urin/Serum-GesamtCitrat während einer $2 \mathrm{~h}$ endogenen Kreatinin-Clearance am Morgen (nüchtern). Diese Befunde erlauben die Annahme, daß

1) eine Citratbindung im Serum vorliegt,

2) der normale Anteil von freiem Citrat am Gesamt-Citrat im Serum bei Steinkranken mit Normocalciurie nicht das bei diesen niedrigere Citrat im Tagesurin erklären kann,

3) unter definierten Untersuchungsbedingungen (morgens, nüchtern) Urin-Citrat weitgehend von der Citratbelastung des Primärharns bestimmt wird. 


\section{Introduction}

Citrate is considered an important chelator of cations such as calcium and magnesium in biological systems like bone and urine. In the latter milieu it reduces the concentration of free calcium ions available for nucleation with phosphate and oxalate $(1,2)$. Therefore, the inhibitory activity of citrate with respect to stoneforming processes led investigators to search for abnormalities of citrate metabolism in renal stone disease.

In a previous (3) and an accompanying (4) study we have been able to demonstrate that, in the absence of primary hyperparathyroidism, urinary citrate excretion during a $2 \mathrm{~h}$ morning clearance period is not different from controls in patients with recurrent idiopathic calcium and uric acid stone formation, although at the same time serum citrate is elevated in stone formers as a whole. This observation prompted the present investigation into possible differences in the citrate fraction freely filtrable at the glomerular level in subgroups of calcium lithiasis, since such a phenomenon might be at least a partial explanation for differences in urinary citrate excretion:

\section{Subjects and Methods}

A total of 36 healthy controls $(\delta / \%=20 / 16)$ from the hospital staff (22-69 years; median 40 ) and 74 non-acidotic patients $(\delta / 8=44 / 30)$ with metabolically active recurrent renal calcium stone formation (20-71 years; median 46) were studied while on their usual home diet. The renal function was normal (serum creatinine $<13 \mathrm{mg} / \mathrm{l}$; endogenous creatinine clearance $>60 \mathrm{ml} /$ $\mathrm{min}$ ) in all subjects, and no other serious illnesses were detectable at the time of examination. Following a $12-15 \mathrm{~h}$ overnight fasting period at home, antebrachial venous blood was drawn anaerobically into $5 \mathrm{ml}$-vacutainers without additive (Becton-Dickinson; Hamburg) at $8 \mathrm{a} . \mathrm{m}$. in the laboratory with subjects seated. Care was taken not to apply stasis to the blood vessel after having punctured it. Then diuresis was stimulated by the administration of $2 \times 300 \mathrm{ml}$ tap water, and a $2 \mathrm{~h}$ clearance period started after bladder voiding. The urinary calcium/creatinine ratio in this period and its response to a test meal in a subsequent $3 \mathrm{~h}$ collection period permitted classification of the patients into the various calciurias (normocalciuria, absorptive, renal leak, bone resorptive $^{1}$ ) hypercalciuria) $(5,6)$. The study of serum citrate fractions was restricted to a limited number of controls $(n=13$; $\delta / q=9 / 4)$, normocalciuria $(n=13 ; \delta / \%=10 / 3)$, absorptive $(n=2 ; \delta / \&-0 / 2)$, renal $(n=7 ; \delta / \%=3 / 4)$, resorptive $(n=5$; $\delta / \$=2 / 3$ ) hypercalciuria.

Technique for determination of ultrafiltrable citrate: to $2 \mathrm{ml}$ of fresh anaerobically handled serum (second $3 \mathrm{ml}$ vacutainer) $\left[1,5-{ }^{14} \mathrm{C}\right]$ citrate (Radiochemical Centre Amersham; England), appr. 1111-1295 $\mathrm{Bq}(30-35 \mathrm{nCi})$, was added and the mixture allowed to stand for at least $15 \mathrm{~min}$ at room temperature. Thereafter it was transferred to a pre-washed $(0.15 \mathrm{~mol} / 1 \mathrm{NaCl})$ visking tube $(<10000$ Daltons; Serva, Heidelberg), which was immediately knotted and inserted into a specially manufactured glass centrifuge tube (7) which was then tightly stoppered. This tube was spun for $3 \mathrm{~h}$ at $3000 \mathrm{~min}^{-1}$ and $37^{\circ} \mathrm{C}$ in a prewarmed JA-21 B (Beckman, Palo Alto) refrigerating centrifuge. The system keeps sample pH below 7.50. Citrate (cold; radioactive) and total protein were measured in both the ultrafiltrate and the supernatant.

1) Resorptive hypercalciuria is synonymous with verified primary hyperparathyroidism.
In addition urinary citrate ( $2 \mathrm{~h}$ morning, $24 \mathrm{~h}$ urine), creatinine ( $2 \mathrm{~h}$ urine only), and serum citrate, creatinine, inorganic phosphate and free fatty acids, were determined in groups of controls and normocalciuric stone patients (for number of observations see results).

\section{Analyses and calculations}

Creatinine was measured by a Technicon-Autoanalyzer, phosphate by a micromethod (8), free fatty acids by micro-titrimetry ( $(9)$, total protein by refractometry, $\left[{ }^{14} \mathrm{C}\right]$ citrate radioactivity in a BF-5000 (Berthold; Wildbad) liquid scintillation spectrophotometer using $10 \mathrm{ml}$ Unisolve cocktail (Zinsser; Frankfurt) per sample $(50 \mu \mathrm{l})$. The citrate lyase method as originally described (10) was used for citrate determination in perchlö̈ic açid $(0.6 \mathrm{~mol} / \mathrm{l})$ extracts of serum $(1 \mathrm{ml}$ serum $+2 \mathrm{ml}$ perchloric acid), while in order to achieve quantitative citrate measurement in urine ( $\mathrm{pH} 5.0-7.8)$, the sample was pre-titrated $(0.1 \mathrm{~mol} / 1 \mathrm{NaOH})$ to $\mathrm{pH} 8.5$ (citrate lyase $\mathrm{pH}$ optimum: 8.2-8.6). Precision (CV\%) was 2.74 (serum) and 1.23 (urine) in repeat determinations $(n=8-10)$ of a given sample (= intraassay CV). Recovery (\%) of citrate added to serum was $97 \pm 7.1$ (ŜD), $99.3 \pm 3.9$ (dilution fáctors in serum extriacts), $99.9 \pm 1.7$ (citrate added to urine), $100.1 \pm 0.6$ (dilution factors in urine), consistent with an overall (0.4-25 nmol/1) complete citrate recovery of $100.0 \pm 1.2 \%$.

Comparability of citrate concentration in ultrafiltrate and serum necessitates corrections for the unit plàsmma water (11) allowing for protein volume (serum) or content of solutes (ultrafiltrate, Donnan factor 1.05). All results are expriessed as means with 1 standard error of the mean. Significance of differences was set at the 5 per cent probability level (Student's t-test).

\section{Results and Comments}

\section{Total and ultrafiltrable citrate of serum (tab. 1)}

Total citrate in controls was in the range reported by others (12) and ourselves (4), using the same method, and the higher mean values in renal stone disease (4) were confirmed. For the first time, to our knowledge, the table provides data on ultrafiltrable citrate obtained with two different analytical methods (enzymatic; radioactivity-related).

The validity of the ultrafiltration procedure has been demonstrated: according to the conceptual model of ultrafiltration outlined by Terepka et al. (11) the protein concentration remaining in the supernatant after centrifugation increases, while the concentration of the ligand under study decreases (so-called sandwich subtraction).

For both citrate and $\left[{ }^{14} \mathrm{C}\right]$ citrate, these two important criteria are fulfilled. If we consider the technique used to be acceptable, there still remains a fraction of serum citrate that escapes ultrafiltration, and which might be bound to serum macromolecules ( $>10000$ Daltons). The fraction of ultrafiltrable citrate varies between 0.86 (controls, normocalciuria, absorptive, renal hypercalciuria) and 0.95 (resorptive hypercalciuria), while with $\left[{ }^{14} \mathrm{C}\right]$ citrate it varies between 0.93 (controls, normocalciuria, absorptive hypercalciuria) and 0.96 (renal, resorptive hypercalciuria).

Only one significant difference is found when we compare the fractions of free citrate obtained with either 


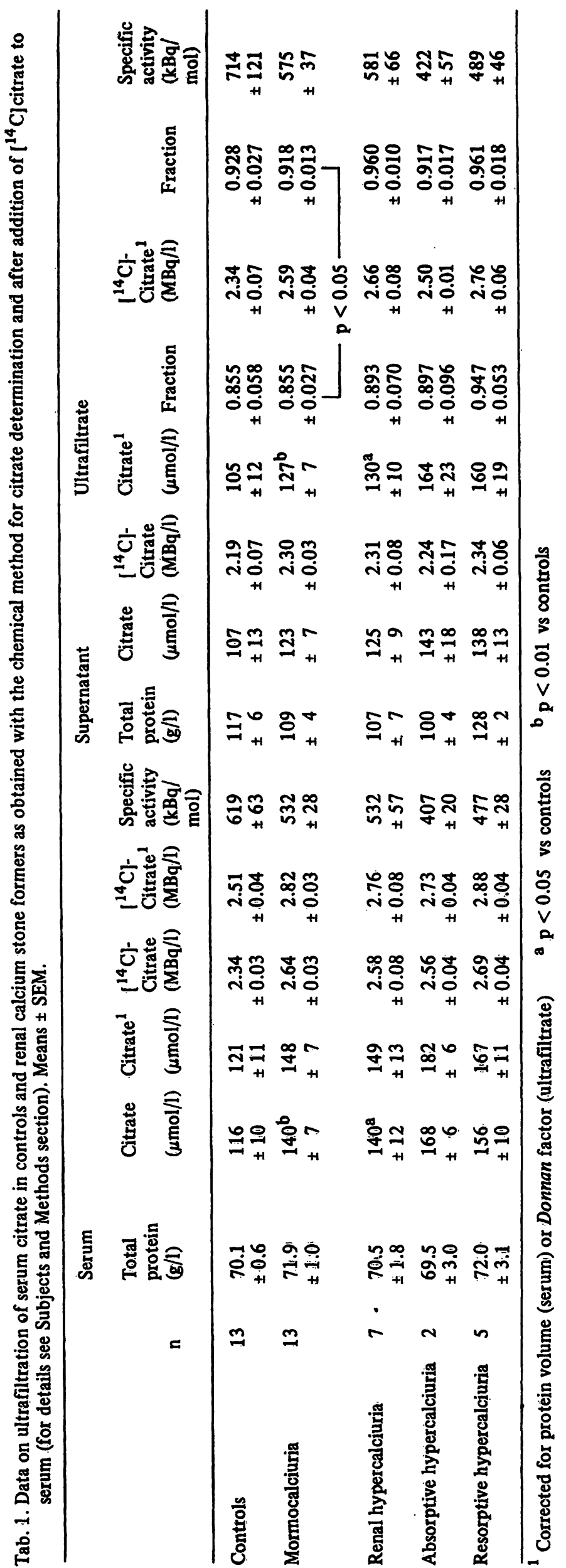

method and this is seen in the normocalciuria. Thus, in this group the rather larger free fraction of $\left[{ }^{14} \mathrm{C}\right]$ citrate may reflect a non-optimal incubation procedure. Non-covalent binding is time-dependent and the chosen period may have been somewhat too short to allow maximal binding. From the stable specific activity in the original and the pertinent ultrafiltrate samples (all groups) there is evidence, however, that citrate and $\left[{ }^{14} \mathrm{C}\right]$ citrate behave identically when exposed to the membrane.

\section{Factors related to citrate binding}

Provided that incomplete ultrafilterability of serum citrate is confirmed by other laboratories, consideration of factors associated with this phenomenon would be worthwhile. Other anions in the serum which are known to manifest partial binding, e.g. phosphate, free fatty acids, and urate, may compete with citrate for binding sites.

This partial binding is less (phosphate; see below), similar (urate (7)) or greater (free fatty acids; see below). However, the present work shows that the fraction of free citrate, and hence that of bound citrate in stone disease does not differ significantly from that of controls.

This seems remarkable in view of the serum concentration of the above constituents in normocalciuria (accounting for approx. 60 percent of all calcium stone formers), which is lower (phosphate; tab. 2) or higher (free fatty acids; tab. 2) than normal, while urate is unchanged (not shown). Assuming a normal serum albumin concentration $(45 \mathrm{~g} / 1)$ and a single class of binding sites in controls and normocalciuria we calculated, in accordance with Goldstein ${ }^{2}$ (13), the following approximate apparent association constants $(1 / \mathrm{mol})$, as based on the mean fraction citrate bound, which had been extrapolated from the mean ultrafiltrable fraction: controls $\mathrm{K}=0.24 \times 10^{2}$, normocalciuria $\mathrm{K}=0.29 \times 10^{2}$. Although these values would fall within the range of urate binding $\left(\mathrm{K}=0.6 \times 10^{2}(7,14)\right)$ they are higher than for phosphate $\left(\mathrm{K}=1.5 \times 10^{1}\right.$ approx. (15)), and much lower than for free fatty acids $\left(\mathrm{K}=1.1 \times 10^{7}\right.$ approx. (16)). Thus normal fractions of free and bound citrate in normocalciuric stone formers is an unexpected finding. One can only speculate as to whether differences in affinity of individual free fatty acids to binding sites or, alternatively, the available number of binding sites; account for this finding.

\section{The relationșip between serum and urinary citrate}

The manner in which citrate arriving in the glomerular ultrafiltrate is handled by the human kidney is largely

\footnotetext{
$\left.{ }^{2}\right)$ using the formula: fraction bound (mol/l) $=\mathrm{n} \times \mathrm{K} \times[\mathrm{P}]$, where $n$ is the number of binding sites, [P] serum albumin $\left(M_{\mathrm{r}}=65000\right)$ concentration, $\mathrm{K}$ association constant.
} 
Tab. 2. Serum concentration of citrate, phosphate, free fatty acids, and citrate output in $2 \mathrm{~h}$ fasting and $24 \mathrm{~h}$ urine of controls and normocalciuric renal calcium stone formers. Means \pm SEM.

\begin{tabular}{llllll}
\hline & $\begin{array}{l}\text { Serum } \\
\text { Citrate } \\
(\mu \mathrm{mol} / \mathrm{l})\end{array}$ & $\begin{array}{l}\text { Phosphate } \\
(\mathrm{mmol} / \mathrm{l})\end{array}$ & $\begin{array}{l}\text { Free fatty acids } \\
(\mathrm{mmol} / \mathrm{l})\end{array}$ & $\begin{array}{l}\text { Urine } \\
\text { Citrate } \\
(\mu \mathrm{mol} / 2 \mathrm{~h})\end{array}$ & $\begin{array}{l}\text { Citrate } \\
(\mathrm{mmol} / 24 \mathrm{~h})\end{array}$ \\
\hline $\begin{array}{l}\text { Controls } \\
(\mathrm{m})\end{array}$ & $\begin{array}{l}109 \pm 4 \\
(34)\end{array}$ & $\begin{array}{l}1.22 \pm 0.03 \\
(36)\end{array}$ & $\begin{array}{l}0.405 \pm 0.03 \\
(30)\end{array}$ & $\begin{array}{l}217 \pm 21 \\
(31)\end{array}$ & $\begin{array}{l}2.78 \pm 0.13 \\
(36)\end{array}$ \\
$\begin{array}{l}\text { Normocalciuria } \\
(\mathrm{n})\end{array}$ & $126 \pm 4^{\mathrm{c}}$ & $1.02 \pm 0.02^{\mathrm{c}}$ & $\begin{array}{l}0.695 \pm 0.049^{\mathrm{c}} \\
(27)\end{array}$ & $\begin{array}{l}234 \pm 17 \\
(58)\end{array}$ & $\begin{array}{l}2.25 \pm 0.16^{\mathrm{b}} \\
(59)\end{array}$ \\
\hline
\end{tabular}

${ }^{\mathrm{b}} \mathrm{p}<0.01$

$c_{p}<0.001$

unknown. If citrate excreted in urine were determined mainly by the filtered load of citrate in the early proximal tubule a rather close coupling of urinary citrate excretion and the filtered load ( $=$ product of endogenous creatinine clearance and free serum citrate) of citrate would be expected, as in the case of substances which either are only filtered (e.g. endogenous creatinine) or are not reabsorbed in substantial amounts beyond the proximal tubule (e.g. phosphate). In the case of unaltered endogenous creatinine clearance in calcium stone formers, a fact well documented, the filtered load of citrate to the proximal tubule would be dependent mainly on free citrate in the serum. We found that the latter and total serum citrate are highly correlated in controls and normocalciuric stone forming individuals $(r=0.974$ and $r=0.932$ respectively) who participated in our ultrafiltration study (tab. 1). These facts lead us to hypothesize that free and bound serum citrate can be predicted from the ratio of the concentrations of creatinine in the urine and serum, and from urinary citrate, provided that there is a sufficiently high correlation between this ratio of both substances. This is recognisably the case in the two groups (controls; normocalciuria) shown in figure 1. It seems therefore, that under the present conditions of examination in the laboratory (morning endogenous creatinine clearance following an overnight fast) urinary citrate is in fact governed by the glomerular filtration rate and serum citrate. The significance of this for practical work is that routine measurements of urinary creatinine and citrate, together with serum creatinine, yield relatively accurate information on the state of serum citrate.

From the above, the unchanged fraction of ultrafiltrable serum citrate (tab. 1) and the normal urinary citrate excretion in all groups during a $2 \mathrm{~h}$ fasting period (tab. 2), it is clear however, that there is a net tubular reabsorption of citrate during health (renal citrate clearance is approx. $10-15 \mathrm{ml} / \mathrm{min}$ ), but considerably enhanced citrate reabsorption in calcium stone disease. If stable serum citrate is assumed, citrate reabsorption in calcium stone disease may be further exaggerated during a $24 \mathrm{~h}$ daily cycle and thereby help to create the now recognized deficiency in urinary citrate of normocalciuric stone-forming individuals (tab. 2; 1.c. 3,4$)$ ). In conclusion, these considerations may help to further the understanding of citrate metabolism and to focus citrate research in calcium stone disease on the kidney.

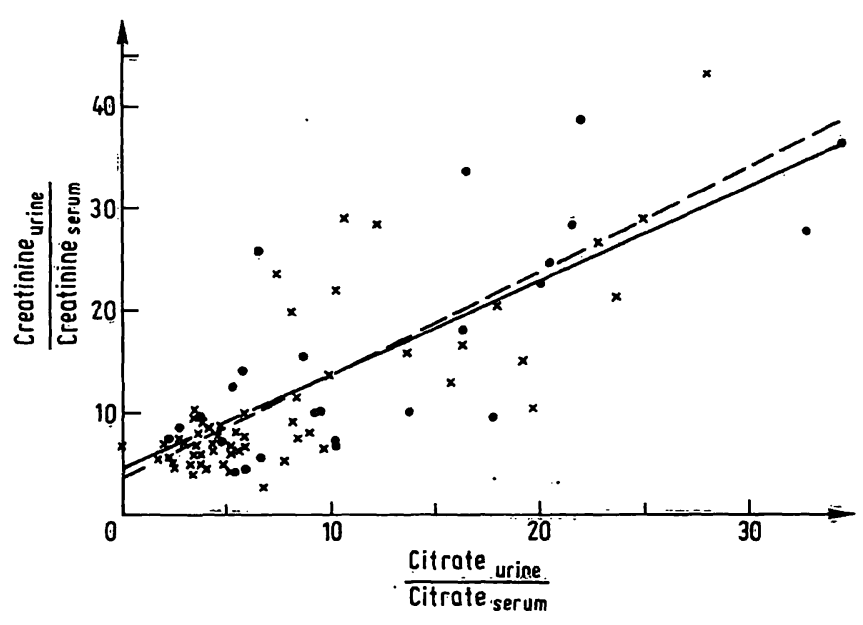

Fig. 1. Relationship between citrate and urine/serum creatinine in controls $(\bullet)$ and normocalciuric calcium stone formers (x).

Regression equations:

1. controls

$\mathrm{y}=0.457+0.091 \mathrm{x}, \mathrm{r}=0.768, \mathrm{n}=25, \mathrm{p}<0.001$

(- = regression line)

2. normocalciuria

$y=0.356+0.10 x, r=0.773, n=56, p<0.001$

(-.-- = regression line).

\section{Acknowledgements}

We are grateful to Universitätsbund Erlangen for a financial grant, and to $I$. Goldberg for technical and secretarial wörk. 


\section{References}

1. Meyer, J. L. \& Smith, L. H. (1975) Invest. Urol. 13, 31 -35.

2. Bisaz, S., Felix, R., Neuman, W. F. \& Fleisch, H. (1978) Min. Electr. Metab. 1, 74-83.

3. Schwille, P. O., Scholz, D., Paulus, M., Engelhardt, W. \& Sigel, A. (1979) Invest. Urol. 15, 457-462.

4. Schwille, P. O., Scholz, D., Schwille, K., Leutschaft, R., Goldberg, I. \& Sigel, A. (1982) Nephron, in press.

5. Pak, C. Y. C., Ohata, M., Lawrence, E. C. \& Snyder, W. (1974) J. Clin. Invest. 54, 387-400.

6. Scholz, D., Schwille, P. O. \& Sigel, A. (1980) Urologe 19 , 202-206.

7. Schwille, P. O. \& Bomhof, C. (1976) Nephron 17, 361-370.

8. Chen, P. S., Toribara, T. Y. \& Hübner, W. (1956) Analyt. Chem. 28, 1756-1758.
9. Braun, J. S. (1971) Z. Klin. Chem. Klin. Biochem. 9, 383-386.

10. Moellering, H. \& Gruber, W. (1966) Anal. Biochem. 17, 369-376.

11. Terepka, A. R., Chen, P. S. jr \& Toribara, T. Y. (1970) Physiol. Chem. Phys. 2, 59-78.

12. Zender, R., de Torenté, C. \& Schneider, U. (1967) Clin Chim. Acta 24, 335-340.

13. Goldstein, A. (1968) In: Principles of drug action, Harper \& Row, New York, 34-40.

14. Campion, D. S., Bluestone, R. \& Klinenberg, J. R. (1973) J. Clin. Invest. 52, 2383-2387.

15. Klotz, J. M. \& Urquhart, J. M. (19489) J. Phys. Colloid Chem. 53. 100-112.

16. Hagenfeldt, L. (1971) Clin. Chim. Acta 32,471-474.

Prof. Dr. Dr. P. O. Schwille Chirurgische Universitätsklinik Maximilansplatz D-8520 Erlangen 
